\title{
Understanding N 603 from Bryggen in Bergen in the Light of Carmina Burana Poems 88 and 71
}

\author{
Egil Kraggerud (University of Oslo)
}

\begin{abstract}
Among the runic texts in Latin from Bryggen in Bergen, N 603 has many attractive qualities: the runic stick is inscribed on three sides ( $a, b$ and $c)$, with each text of approximately equal length and syntactically and logically complete (although with minor lacunae at both ends). The texts reveal great intelligence and independence on the part of the cleric who composed them. Each of the texts contributes to the summary of a message from a lover to his beloved lady. Aslak Liestøl, who submitted the rune-stick to a thorough investigation and analysis, ably demonstrated that certain stanzas known from the Carmina Burana collection of love poems (no. 88 and no. 71) formed the basis of the texts. He did, however, leave some difficulties unresolved. There are, for example, a few Latin concepts which benefit from further semantic discussion. In addition, the slightly damaged stick still offers its interpreter some challenges. It is to be hoped that a closer reading of the poems in question will show that a fuller reconstruction of the wording of the rune-stick's text is possible.
\end{abstract}

Keywords: N 603 Bryggen in Bergen, Carmina Burana, Latin love poetry, textual reconstruction, virginity, chastity

$\mathrm{T}$

The first and only medieval transmission of verses from the Carmina Burana in Norway came to light on a rune-stick found at Bryggen (The Wharf) in Bergen during archaeological excavations in 1961. The Carmina Burana ( $C B$ in references hereafter) is a manuscript from the Benediktbeuer Abbey in Bavaria containing a large collection of secular lyric poetry. Most of the poems and songs were probably composed by

\footnotetext{
Kraggerud, Egil. "Understanding N 603 from Bryggen in Bergen in the Light of Carmina Burana Poems 88 and 71."

Futhark: International fournal of Runic Studies 11 (2020, publ. 2021): 137-53. DOI: $10.33063 /$ diva- 438138
} 
Goliards, i.e. itinerant (clerical) medieval students; they are often satiric and typically celebrate licentiousness and drinking.

The stick is archaeologically dated to c. 1250, having been found in the foundations of a building constructed soon after the conflagration at the wharf in 1248. The piece is now $114 \mathrm{~mm}$ long but is broken at both ends. It has been shaped to four smooth sides with a quadratic cross-section measuring $9 \times 9 \mathrm{~mm}$. There are runes on three of the four sides, with some missing at the beginning and end of each line. The inscription was published by Aslak Liestøl in 1980 in the first fascicle of the sixth volume of Norges innskrifter med de yngre runer (NIyR in references hereafter) as N 603 (NIyR, 6: 1-9). His reading is as follows (p. 1, but with James Knirk's minor corrections from pp. $227 \mathrm{f}$., including $\mathbf{v}$ as the transliteration of the dotted $u$-rune in vilum·ena):

a) --.]grẹ:gie:igni:bus:kâlẹ[e<a]sko:æius:koti:die·inamore:græs:ko[--

b) - - . ]ṣ:agam:teneri:uirgo:sik·agamus:ambos:ṣ[s<i]umuṣ[--

c) --.]n[..]a:lusis:agone:vilum·ena:kuæruli:tæriar[.--

In connection with work on a Festschrift article, James Knirk requested that the present author reconsider the text to add to understanding of the quotes from Carmina Burana in order to review the relationship between the poems and the inscription (cf. Knirk 2017, 224).

In the following I refer constantly to Liestøl's analysis in the hope that readers will have $N I y R$, vol. 6, near at hand. I have only one serious complaint concerning his valuable and learned account, namely the way he dealt with the relevant Carmina Burana poems. The only translation appended to his scholarly publication of $\mathrm{N}$ 603, that of Amor habet superos ( $C B$ no. 88, hereafter $C B$ 88), is a highly dubious one. Sigmund Skard (1903-95), a professor of literature, a knowledgeable translator and a poet in his own right, was far too free in his rendition of the poem for it to serve as a reliable guide for users of the Norwegian corpus edition. Liestøl has also left out the refrain, which can be regarded as the poem's most important element since it highlights the main message of $C B$ 88. The second poem, Axe Phebus aureo ( $C B 71$ ), is altogether more complicated and difficult, but is even less accessible as it is left untranslated in Liestøl's analysis.

In view of the derivative nature of the runic inscription, it is legitimate to problematise its genesis in the widest sense. There is to begin with an anonymous goliardic poet behind each poem ( $C B 88$ and $C B 71)$, probably not the same man behind both. The poems exhibit some variants in the 
critical apparatus in Schumann's edition (1941); even the structure and order of stanzas may at times differ. I do not, however, consider it within the scope of this study to discuss the Carmina Burana collection and its transmission as the first stage in the genesis of the inscription. The dating of the poems and their milieu are highly interesting topics in themselves, but of scant relevance for any understanding of the runic inscription I am dealing with. (For the most complete modern edition of Carmina Burana, see Vollmann 1987/2011.)

The three "texts" (sides $a, b$ and $c$ ) reflecting the specific poems $C B 88$ and 71 were devised for a specific purpose. The quotations must count primarily as summarised adaptations, of little interest for issues related to the textual transmission of the Carmina Burana songs. A man deeply familiar with the lyrical content was evidently competent enough to make his chosen material fit a new medium, the stick. We cannot be certain whether it was the same man or another, namely the carver, who transliterated the Latin texts into runes.

My hypothesis is that these verses, regarded as completed entities, are indispensable both for filling out the runic text satisfactorily and, perhaps, for understanding the stick's cultural context. For this reason I will try to illuminate some issues by prefacing my comments on the stick with a translation of $C B 88$ and $C B 71$ respectively. My rendition follows Liestøl's textual versions with little discussion of the textual tradition. Thus the fourth stanza of poem 88 in Hilka and Schumann's edition (1930-41), accepted by Liestøl, is for instance the third stanza in the versions printed by Günter Bernt in his widespread Reclam edition (1992). However irrelevant this may seem for the main problems affecting $\mathrm{N}$ 603, it can hardly be denied that the earlier position of this stanza as the third, immediately after the mythological preamble, makes the 'I' and his girl more conspicuous as a romantic twosome in the poem. Additionally, the ninth stanza, which is the final one in my translation below (as in $N I y R$ ), is often taken as the eighth (cf. Bernt). Irrespective of the sequence and even number of stanzas, however, the fullness of $C B$ 88 and 71 below provides a highly relevant overall view of the general ideas.

In my translation I include after stanza 1 the refrain Amoris solamine/ virgino cum virgine;// aro non in semine,/ pecco sine crimine, with the translation underlined. I mark the words and letters preserved as runes on the stick in bold (with serifs). The slashes are meant to reflect the wellknown type of metrical units (couplets or distichs) that are so evident in the rhythm of $C B$ 88. (The Latin text is printed in $N I y R, 6: 2 \mathrm{f}$.) 
1. Amor (Love) has the divine beings in his power: Juno loves Jupiter;/ while restraining the ferocious waves he (Amor) commands Neptune;/ Pluto who controls the inhabitants of Hell is mild because of him alone. Refr. As a solace for my love/ I am virginally chaste with my virgin;/ I do not plough with seed,/ I sin without transgression. 2 . Love attracts the young with a softer bond;/ the rigid and the coarse ones it defeats with forceful bending;/ "the rhinoceros" is caught in a virgin's embrace. 3. As a virgin among virgins I shudder at depraved women,/ and, in addition to harlots, I detest married women;/ because in such women there is disgraceful lust. 4. In my passion for an outstanding virgin I am getting hot,/ and in my love for her I am getting stronger day by day;/ the sun is in its zenith, and I am not becoming lukewarm. 5. Dear above all is playing with the girl,/ and her breast is without any gall;/ the kisses she is offering are sweeter than honey. 6. I play with Cecilia, don't be afraid!/ I am a sort of guardian for her tender age,/ in order that the lilies of her chastity shall not wither. 7. She is a flower: to break a flower is no carefree thing./ I let the grape grow until it is mature./ Hope makes me live as a happy man concerning the future event. 8. I will only play, that is: "look at",/ "address" face to face, "touch", finally "kiss"; "the fifth", which is to do it, do not suspect that! 9. Whatever the others may carry out, my virgin, let us act in such a way,/ that we will do playing that is carried out decently:/ we are both tender; let us play tenderly.

For the presentation below of the fourth and the ninth stanzas in Latin, i.e. texts $\mathbf{a}$ and $\mathbf{b}$ on sides $a$ and $b$ respectively, the capital letters in bold correspond to legible runes, square brackets [ ] indicate illegible or lost parts, ordinary parentheses ( ) signify text which has been ignored or left out and italics text which has no equivalent on the stick. The superscript numbers mark the couplets (distichs).

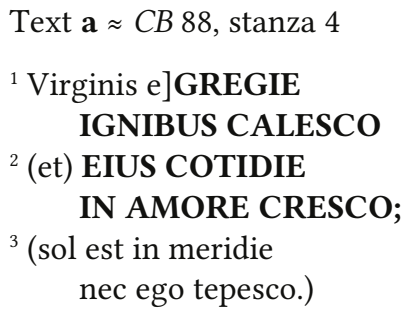

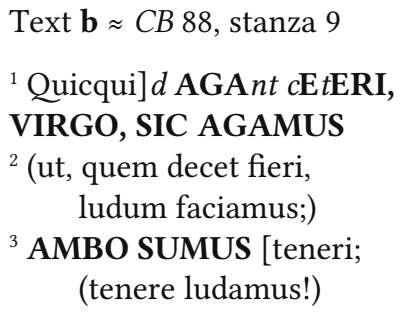

The goliardic rhythm of the Carmina Burana poems, not least discernible in $C B 88$ with its recurring couplets ( $7+6$ syllables) and rhymes, is often strikingly effective; the natural stress of the words agrees regularly with the verse ictus (viz. metrical stress). See for example the first couplet above $\left(\mathbf{a}^{1}\right)$ that can be marked like this (acutus for the main and gravis for 
the auxiliary stress): Virginis egrégiè/ ígnibùs calésco. This rhythm lends itself to singing. The fact that we perceive lines 1 and 2 in $\mathbf{a}^{1}$ both as individual lines and as a couplet is due not least to the strong caesura or break after the seventh syllable whereby the longer first line both begins and ends with a stressed syllable while the second line ends with an unstressed one. The alternating rhythmical closures of the lines are underlined by the rhyme scheme and its repetition in each couplet $\left({ }^{1}-G I E\right.$,

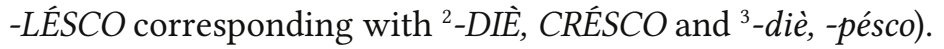

Minor exceptions to the concurrence of word accent with verse ictus appear where an initial monosyllabic word is followed by a bisyllabic one (here with ictus marked with a gravis): ét eiùs $\left(\mathbf{a}^{2}\right)$, not: eíus (cf. $\mathbf{a}^{3}$ néc egò). On this basis there is an understandable lack of enjambment (i.e. a syntactical 'overstepping' or continuation of the line without a pause), a fact contributing to the impression of regularity in the stanza structure.

\section{Commentaries on texts $\mathbf{a}$ and $\mathbf{b}$}

\section{Text $\boldsymbol{a}$}

The runic text on side $a$ is the most straightforward of the three. The carver has rendered the two distichs from $C B 88$, st. $4^{1-2}$, on his stick (cf. NIyR, 6: 1) verbatim. The missing runes before GREGIE can therefore safely be supplied as having contained the text virginis $e$ - The omission of $e t$ at the start of the second couplet is perhaps not due to the need to save space. As can be seen from $\mathbf{c}^{1}$ below, with its Latin iocis agone/ relevat cruciat, asyndeton-the omission or absence of a conjunction between parts of a sentence-is a common stylistic device in goliardic poetry; therefore, the phenomenon may simply have been imitated by whoever composed these texts. This same person did not, however, consider the effect of the omission on the poetic scanning or singing of the text. Nonetheless, the agreement between the stick and the poem is so close that the runes can be regarded as a verbatim quotation. The importance of this in regard to the three texts as an ensemble is discussed below.

\section{Text $\boldsymbol{b}$}

The runic text on side $b$ (Liestøl 1980 in NIyR, 6: 1, with Knirk 1990 in NIyR, 6: 227; Knirk 1998, 499) contains the first serious difficulty, leading to some hypotheses about the composer's technique. For the text of stanza 9, I have followed Schumann (1941) in reading ceteri 'the others' in the 
first line; ceteri is without doubt the original and "correct" word although Liestøl (p. 4) allows the possibility of an alternative and synonymous alii, which is without relevance to the present analysis. The rhyme scheme is a decisive factor in favour of ceteri (cf. ceteri-fieri-teneri) and in all likelihood lies behind the text known to the author of the inscription on the stick although he chose not to adopt it.

An analysis of the syntactical structure of $C B 88$, stanza 9, in relation to the runic text is useful.

Quicquid agant ceteri, virgo, sic agamus, ut, quem decet fieri, ludum faciamus;

ambo sumus teneri; tenere ludamus!

\author{
Whatever the others may carry out, \\ my virgin, let us act in such a way, \\ that we will do playing \\ that is carried out decently; \\ we are both tender; \\ let us play tenderly!
}

The stanza's original structure is as follows. (Note that the conscious employment in the following of a number of technical grammatical terms-easily accessible in dictionaries and grammars-is meant in itself to demonstrate the complicated structure of the stanza.) A subordinate relative clause (generic quicquid with the subjunctive agant) is followed by three clauses, the predicates of which are subjunctives forming the second row of rhyme-words (agamus, faciamus, ludamus) and constitute the stanza's framework so to speak. The syntax itself, however, is rather intricate: agamus and ludamus are subjunctives that serve as quasi imperatives in main clauses whereas the subjunctive faciamus is subordinate to agamus in a consecutive clause (ut .. . ludum faciamus), itself encompassing a relative clause that defines ludus as 'decent' (quem decet fieri). Such intricacy was understandably not preferred by the runic author. His focus is instead on the other simple main clause with its straightforward message in the indicative, ambo sumus teneri, which in the original stanza followed sic agamus ... ut ...faciamus and constituted a conclusion in the form of an explicative asyndeton: "we are <namely > young and tender both of us".

As regards the content of the Carmina Burana stanza in relation to the whole poem we can say this much: the jussive subjunctives (agamus, ludamus, here hortatory 'let us ...')-the first of this grammatical mode in poem 88-convey the impression of summing up an important message as the poem approaches its end (regardless of whether the stanza was originally the last or the penultimate). The lovers, then, seem to be attached to each other on the basis of a strictly moral (and Christian) code of behaviour prescribed by the previous stanzas (and suggested in the refrain). 
A remarkable feature of the ninth stanza is the choice of words, albeit with varying shades of meaning: agere in the first line is to 'undertake', 'make', 'carry out' in a broad sense (including intercourse, cf. quicquid 'whatever'); this use of agere has been signalled more specifically in the last couplet of the eighth stanza (see below). There, agere signifies no more than 'behave in a decent way as lovers' in the second line. This curtailing of its semantic range suggests a definition of the noun ludus and the verb ludere which indicates 'a decent erotic playing' between the lovers.

Finally, we are able to "correct" one letter in the runic inscription, bearing in mind that the $i$-rune in Old Norse inscriptions at the time could still be used for $e$. The word teneri (nom. pl. of the adj. tener) is no longer possible; only the adverb tenere is meaningful. This is taken from the last line of stanza 9. We can also elicit semantic distinctions from the pair teněrē (adv.) and tener (adj.) based on the lesson of the stanza: tener has more to it than 'tender'; it is coloured by the shy inexperience of young lovemaking that is amply described in previous stanzas. The rhyme scheme suffers from this correction, however: the semantic repetition of tener (as in stanza 9!) was more important for the composer of the text on the stick than rhyme.

Considering the rune-stick's text from the angle of this analysis allows us to suggest not only that runes 28-37 (NIyR, 6:1) transliterate line 5 of stanza 9 ambo sumus, but also that the missing section of the runic text, equivalent to teneri in Carmina Burana, was meant as a sort of conclusion, the style of which I hope will gradually emerge more clearly. To be specific: ambos (for ambo) is a mistaken nominative and not acceptable by the educational standards of the 1200s; ambos was probably influenced by the common medieval (alternative) accusative ambos or it could have been a scribal error due to the following word beginning with $s$. The form would hardly deserve mention in a grammar such as Stotz's (on the possible inflections of this word see Stotz 1998, § 87.2 [vol. 4: 165]).

Runes 19-27 are equally clear: the poem's second line (virgo, sic agamus) is faithfully transliterated. But since lines 3 and 4 , i.e. couplet ${ }^{2} u t \ldots$ faciamus, are left out the stick's sic cannot point forward as in the poem; sic must now seek its reference in the previous part of the runic text. The problem does not end with this change of reference but the vocative virgo is also affected: does the address to the beloved belong to the previous sentence (with agam as predicate) or to the following sentence (with agamus)? Both options are possible. A casual reader of the rune-stick will most easily combine the address with the first sentence, taking it as a promise: agam tenere, virgo. But one mindful of the poetic inspiration will 
take virgo with the urgent request agamus and influenced by the strong caesura. Preference for the first alternative implies-most probably in my opinion-that sic refers to the previous adverb tenere: "Let us behave/act gently like that" whereupon follows the explicative asyndeton (without a conjunction, as in the poem) ambos etc.

The freedom exercised by the rune-stick's composer has so far become evident, although it is far from radical: he reduces, and changes the tense, mode and number of a basic concept (agere); in short, he has in a way freely "edited" a text he appears to have known well as a poem.

Does the stick also deviate more fundamentally? We are lucky that minute remains of a short-twig s-rune $\left({ }^{\mathfrak{d}}\right)$ after the break at the beginning of line $b$ are, although uncertainly identified, highly probable. It is almost with relief that the present writer ascertains that there is no evidence that the final "letter" in the preceding word could have been a $d$-rune, as otherwise we would have had to consider whether to supply quicquid from the poem ("whatever I will do gently"), which would be contrary to the basic meaning of the poem. Accordingly, a word ending in $-s$ is needed which aligns with the context. Now the carver has replaced 'the others' (ceteri) with the 'I' person (cf. 1st pers. agam) as the stick's protagonist; and instead of the generic subjunctive of the poem's line, he has a homonymous future indicative agam. In this way agere already shows the 'decent' meaning it has later in the original stanza. The 'I' represents everywhere an acceptable sexual behaviour emphasised by the adverb tenere as used in the last line of stanza 9 (tenere ludamus).

What, then, is the missing Latin word ending in $-s$ ? In view of the great number of possible words and inflectional forms, it is useful to look for a word based on the poem's own text, in which case the word form for filling the lacuna is rather conspicuous. I am basing my hypothesis on the following line of reasoning: the part equivalent to Quicquid agant ceteri and its agant is more than the result of a change of tense, mode and person: it somehow restores the male character, the essential 'I' dominating the inscription's text a. The focus on him is as great in the stick's $\mathbf{b}$ text as in a; the responsible attitude shown by the male lover attracts attention after his candid confession of increasing love in text $\mathbf{a}$. In the first part of $\mathbf{b}$ he is evidently uttering a serious pledge before he urges his beloved to act in the same spirit as him. He adopts, as it were, the moral attitude to love evidenced by the moral stance in the poem's stanza 8 (Volo tantum ludere etc. 'I will only play ...') where the 'I' holds forth on the concept of ludere and what it means to him. He gives a sort of mini catechism on love by presenting as his teaching the forms of lusus 'game, playing'. The playing 
has an ascending order of intimacy through its five acceptable steps: (1) contemplari 'to look at', (2) loqui 'to speak to', (3) tangere 'to touch', (4) osculari 'to kiss'; as regards the final "fifth" step, he explicitly and firmly states that nobody (and she in particular!) should suspect that he might have in mind such a thing as agere: quintum, quod est agere,/ noli suspicari ("the fifth, which is "to do it", do not suspect that!'). Stanzas $3+4$ and $8+9$, then, inspired the core of the poem's 'I' story on the stick; the formal aim of the composer of the texts is to amalgamate and condense this message without loss of any significant part thereof. Accordingly, it should be no surprise that the $\mathbf{b}$ text also reflects the context of the eighth stanza. A closer look at the eighth stanza in the poem shows that it has an emphasised adjective in its catechism, the only one in fact, presens, in the grammatical function of a predicative adjective, i.e. '<being > present' (we would rather say 'in her presence', 'face to face' or something similar): Volo tantum ludere,/ id est: contemplari,/ presens loqui, tangere,/ tandem osculari;/ quintum, quod est agere,/ noli suspicari! ('I will only play, that is: "look at", " "address" face to face, "touch",/ finally "kiss"; "the fifth", which is "to do it",/ do not suspect that!') The adjective presens formally belongs to loqui but also acts as a kind of heading for steps 3 (tangere) and 4 (osculari); in all three cases it is (as a matter of course) equally true. It must have been important for the author to add this predicative adjective to his agam tenere: he was thus better able to evoke the quintessentially ethical attitude of the poem that inspired him. Presens is, moreover, a bisyllable like quicquid. It is perhaps a coincidence that text $\mathbf{b}$ can be scanned as one and a half goliardic couplets.

This, then, is the $\mathbf{b}$ text before its transliteration into runes according to my analysis:

presens agam tenere, virgo; sic agamus: ambo sumus teneri

'Face to face I will act tenderly (gently), O virgin; let us act in such a way: we are both of tender age.'

\section{Commentary on text c}

Liestøl demonstrated in 1980 that text $\mathbf{c}$ in the third and final line corresponds to the text in stanzas $3^{\mathrm{b}}+2^{\mathrm{a}}\left(\right.$ ?) $+2^{\mathrm{b}}$ of $C B 71$ Axe Phebus aureo (cf. NIyR, 6:5; here with the same conventions as above: letters corresponding to runes in bold capitals, damaged or lost text indicated by brackets [ ], lines omitted in parentheses, and in italics text which has no equivalent on the stick). 
$3^{\mathrm{b}} \quad$ Iamque Dione

ioCIS AGONE

relevat cruciat

corda suorum.

$2^{\mathrm{a}}$ (?) (Aurarum suavium

gratia iuvante)

sonat nemus avium

voce modulante.

$2^{\mathrm{b}}$ PHILOMENA QUERULE TEREA R[etractat

(dum canendo merule carmina coaptat)
And now Dione

-in jest, in distress-

soothes, tortures

the hearts of her people.

(While the pleasure

of mild breezes delights,)

the grove resounds

with the birds' melodious song.

Philomela withdraws from

Tereus in her plaintive way

(while in her song she unites her tunes

with those of the blackbird)

The following is my translation of the entire poem $C B 71$ (for the Latin text see Liestøl 1980 in NIyR, 6: 4-6).

$1^{\text {a }}$ Phebus traverses the higher regions in his golden chariot/ and in rosy glow he lets his beams shine forth. $\mathbf{1}^{\mathrm{b}}$ Adorned with a flowery countenance Cybele bestows/ flowers on the son of Semele with the blessings of Phebus. $2^{\text {a }}$ While the pleasure of mild breezes delights,/ the grove resounds with the birds' melodious song. $2^{\text {b }}$ Philomela withdraws from Tereus in her plaintive way while in her song she unites her tunes with those of the blackbird. $3^{\text {a }}$ The happy choir of Dione now resounds zealously with its songs. $3^{\text {b }}$ And now Dione-in jest, in distress-soothes, tortures the hearts of her people. $4^{\mathrm{a}} \mathrm{Me}$ as well she deprives of sleep and forces me to be awake from love. $4^{\mathrm{b}} \mathrm{I}$ am carrying about the golden arrows of Cupid, my heart burning with disturbing fire. $5^{\text {a }}$ That which is given to me I am afraid of, and what is denied me, I desire seriously. $5^{\text {b }}$ The girl giving in to me I keep away from; the girl that is not compliant I favour-and I am in fact $\mathbf{6}$ unhappy, whether I perish or am relieved through her. The covetous girl I shun; the evasive I long for. The more I reject my duty, the more I am drawn towards the forbidden; the more the unlawful is allowed, the more the illegal pleases. $7^{\text {a }} \mathrm{O}$ you, terrible decisions of Dione, O you, disgusting secret poisons, fearful in your fraud and filled with deceit. $7^{\text {b }}$ Skilled in punishing with furious passion those whom she lets endure love's bitterness, (a bitterness) full of burning jealousy and wrath. $\mathbf{8}^{\mathrm{a}}$ Hence fear abounds for me, hence tears overflow my face. $\mathbf{8}^{\mathrm{b}}$ Hence there is pallor in my face because I am betrayed by love.

It is immediately evident that text $\mathbf{c}$ has a more complicated origin and is more difficult than texts a and $\mathbf{b}$. The poet behind $C B 71$ is also more ambitious. While $C B 88$ had the god Amor at its centre, the learned poet of no. 71 instead names Cupid and his grandmother Dione as his gods 
of love. Whereas $C B 88$ depicts Amor's happy and beneficent wielding of power, the poem Axe Phebus aureo is ambivalent. After describing in three rhythmically homogeneous stanzas $\left(1^{\mathrm{a}, \mathrm{b}}, 2^{\mathrm{a}}\right)$ the all-embracing light of Phebus, the delight of Cybele in nature and the joyous song of birds in spring, the poem suddenly changes character with the Philomela myth (see the "Appendix" below) and concentrates on the ambiguous goddess Dione. Dione causes both happiness $\left(3^{\mathrm{a}}\right.$ and $\left.{ }^{\mathrm{b}}\right)$ and distress; the 'I' suffers from the unhappy effects of her display of power: as a consequence his behaviour towards girls is quite irrational and confused. His experience of love turns out to be utterly negative: fear of poisonous deceit causes bitterness and the sensation of being punished for his passion. Instead of feeling the bliss of love, he becomes the victim of jealousy and fury, grief and tears.

The contrast with texts $\mathbf{a}$ and $\mathbf{b}$ must in some way be relevant for comprehension of the three texts as a whole. It is easy to concur with Liestøl (NIyR, 6: 5) that the text of line c on the stick "ser ut til å ligge endå lenger borte frå parallelltekstane enn dei to første linene" (seems to be more distanced from the parallel texts than the first two lines). Above all, the composer demonstrates a freedom already evident in the first couplet in text $\mathbf{b}$, which consists of creating an amalgamation of a wider context. The text here relates to three or perhaps four stanzas of $C B 71$, namely $\mathbf{2}^{\mathrm{a}, \mathrm{b}}$ and $\mathbf{3}^{\mathrm{a}, \mathrm{b}}$. Thus it is unsurprising that the runic text inverts the order of the transmitted stanzas by quoting $2^{\mathrm{b}}$ after the reference to $3^{\mathrm{b}}$. The poem acts as the source of an idea rather than a poetic quotation, and the author is free to change words or substitute synonyms, in short, to do whatever befits a message limited to around fifty runes on each side of the stick. Unsurprisingly therefore, we find in c: (1) that he juxtaposes AGONE and PHILOMENA although these words belong to separate stanzas in $C B 71$, (2) that instead of iocis as in Carmina Burana he writes lusis, (3) that the text missing at the beginning of the line could hardly have been Iamque Dione.

I will comment first on the details of the reliable latter part, filumena querule terea r [etractat]. The runic form normalised Filu- (or preferably Filo-) of the first word Philomena has been discussed by Liestøl (p. 7). I assume with Liestøl that our author may have pronounced the $P h$ as transmitted by $C B 71$ as a bilabial spirant [w], since the carver did not use the standard $f$-rune but rather a dotted $u$-rune. Although Liestøl transliterated this as an uncertain $\mathbf{f}$, Knirk in his corrections and additions (NIyR, 6: $227 \mathrm{f}$.) suggested instead transliterating it with $\mathbf{U}$ or $\mathbf{v}$ in order to maintain the one-to-one correspondence between runic forms and transliterations; his preferred $\mathbf{v}$ (pers. comm.) has been used in this article. We should also bear in mind that 
$f$ for $p h$ was close to standard orthography in medieval Latin (Stotz 1996, sect. VII, § 143 [= vol. 3: 178]). It is likely that -o- would have been regarded as correct in the spelling of the name in Latin, but the carver may have believed that what he heard should be written - $u$ - (thus Liestøl, p. 7).

As regards the latter part of the name, -mena, much could certainly be added to Liestøl's brief comment: "I mellomalderen var det vanleg at andre lekken i namnet hadde $n$ for det opphavlege $\lambda$ in $\Phi \iota \lambda$ o $\mu$ í $\lambda \alpha$ " (In the Middle Ages it was common for the second part of the name to have $n$ instead of the original $\lambda$ in $\Phi \iota \lambda$ o $\mu \eta \dot{\eta} \lambda \alpha)$. It is in fact unclear how and when this distortion of the name arose. Stotz (1996, sect. VII, § 292.10, n. 57 [= vol. 3: 338]) names Agnellus from Ravenna in the 800s as his earliest example; by the time of Chrétien de Troyes it was the title of his 'conte' in the 1170s. The original form Philoméla has long $\bar{e}$ and stress on the penultima in Latin; in Greek an acute accent is on the $\eta$ because the final $\alpha$ is long (this was, however, shortened early on in Latin). $\Phi \iota \lambda \circ \mu \eta \dot{\eta} \lambda \alpha$ is the feminine equivalent of the name $\Phi \iota \lambda$ ó $\mu \eta \lambda \mathrm{o} \varsigma$ and consists of $\varphi \iota \lambda_{0}-$ 'dear', 'fond' and $\mu \eta^{\prime} \lambda-^{1}$ 'apple' or (preferably) $\mu \eta^{\prime} \lambda{ }^{2}$ 'sheep and goats', Norw. 'småfe'. Independent of this name there was in antiquity a female

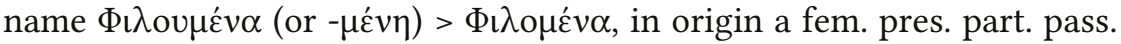
of $\varphi \iota \lambda \varepsilon \tilde{v} v$ 'to love', meaning 'the beloved (girl)', found from classical times also in the masculine form ending in -oc. Whether this influenced the distortion of the name Philomela, I cannot tell. I am uncertain whether the mythical Philomela, known from Vergil and in particular from Ovid, was called Philomena (with long $\bar{e}$ ) between the 800s and the 1300s in any of the many manuscripts of Ovid's Metamorphoses. No indication of this is found in Anderson's (1982) critical text of the Metamorphoses.

A more important question is this: should our author's 'Philomena' be written with an initial capital (as a nomen proprium) or with a lower-case letter as an appellative (reflecting the fact that the mythical characters Philomela, Procne and Tereus were changed into birds). Wetmore's Index verborum Vergilianus (1930) rightly shows two lemmata, one for each case. In $C B 71$, st. $2^{\text {b}}$, Philomena (= the nightingale) and Tereus (= the hoopoe) are singing birds (cf. avium voce modulante) just like the merula (= the blackbird, mentioned immediately afterwards in $2^{\mathrm{b}}$ but not on the rune-stick).

A reconstruction of the missing word at the end of the runic line as representing retractat can hardly be contested, even though only the initial $\mathbf{r}$ is preserved before the lacuna; this provides the only certain finite verbal thus far. The translation is, however, more problematic. Liestøl translates: 'strittar ... mot', that is 'resists', 'strives against', which implies a physical 
struggle, a reasonable enough idea in itself since Ovid tells of the rape of Philomela by King Tereus (Metamorphoses $6.524 \mathrm{f}$.: et virginem et unam/vi superat 'overcomes her with force [Oxford Latin Dictionary, s.v. vis 2a], <as she is $>$ a maiden and alone'), but transitive retractare as used in Carmina Burana is peculiar and lacks parallels. The meaning of retractat here must be sought in its intransitive usage in classical Latin 'to draw back (in doubt or reluctance)', 'hang back', 'shrink' (thus Oxford Latin Dictionary, s.v. A.3). Norwegian would here prefer a reflexive expression 'trekke seg tilbake', 'holde seg tilbake'. The transitivisation is most easily explained as an imitation of Vergil's use of the verb at Aeneid 12. 889 (preceding the single combat between Aeneas and Turnus, the climax of the epic): Quae nunc deinde mora est? Aut quid iam, Turne, retractas? ('What sort of delay is there still? Or why, Turnus, do you now draw back?'). This latter sentence may have been taken transitively as if an elliptic acc. me were to be supplied. Thus Terea retractat should be taken as 'draws back/shrinks from Tereus' (Norw. 'trekker seg tilbake fra Tereus').

We then have a regular (perhaps accidental) goliardic couplet $(7+6$ syllables):

\section{fíloména quérolè/ téreà retráctat}

We turn now to the remainder of the legible text, a lusis agone. The runes lusis were taken by Liestøl as lucis, gen. sg. of lux 'light', possibly 'day' (NIyR, 6: 7, cf. Word Index p. 268), but I find no support for this in the relevant stanzas of CB 71. Taking the word as an ablative pl. of lusis, a (substantivated) perf. part. of ludere 'play' is even less convincing. We are then left with abl. pl. of lucus 'grove', as strongly suggested by the setting of stanzas $2^{\mathrm{a}}$ and ${ }^{\mathrm{b}}$.

The following word form, agone, represents two interconnected problems, namely the meaning of agon and its syntactical placement. It is worth noting that agon is a loanword from Greek in Silver Latin (from the first century AD): 'struggle', used particularly of gymnastic or musical games and contests. This meaning is known from Suetonius: cf. musicus agon 'contest in music', 'musical competition' (Suetonius, Nero 22.3, 23.1), so the abl. sg. agone might mean 'in competition'. Agon was appropriated by Latin Christianity to signify the spiritual struggles of Christians, in particular the sufferings of martyrs. In $C B 71,3^{\mathrm{b}}$ Dione ... agone ... cruciat corda suorum expresses the idea that the goddess tortures the hearts of her people through (a life of luckless) struggle and travail.

The reading a lucis provides a clue to the missing first part of $\mathbf{c}$ : lucus (or as generalising pl. luci) is synonymous with $C B$ 's (generalising) sg. nemus, 
originally a loanword from Greek, whereas lucus is the more common synonym for 'grove'. In $C B 71$, st. $2^{\mathrm{a}}$, the nemus is the scene of singing birds (in spring); the abl. lucis on the stick shows that we are concerned with a syntactical construction different to the one in the poem. The preceding $a$ is followed by word division, although there is none preceding it; we can however compare text a (cf. NIyR, 6: 1), with word division before in (:inamore:), but not after. This is common after, but not before, monosyllabic prepositions in runic inscriptions and in Old Norse manuscripts from that time, according to James Knirk (pers. comm.). Still it may yet be possible that word division before $a$ was dropped here. Separation was otherwise somewhat erratic, and in fact often overused in the Carmina Burana texts here, even between word elements (cf. colon or raised period inserted in [e]gre:gie igni:bus ... coti:die ... cres:co ... filum.ena).

Accordingly, I am reasonably convinced that a lucis means 'from the groves'. In reference to the separative use of $a$, cf. Bourgain and Hubert 2005, 38: "sa function séparative s'élargit (et empiète sur le terrain de ex ou de l'ablatif séparatif)". Likely words before a lucis are avis/aves (sg./pl.) or 3rd pers. sg. or pl. of sonare 'to sound' or cantare 'to sing' or the synonymous canere. The remains of four damaged runes before the preserved $a$-rune in a lucis show a certain $\mathbf{n}$ in second position (as already identified by Liestøl), and as James Knirk has pointed out (pers. comm.), this eliminates most of these possibilities; the certain $\mathbf{n}$ also removes the verb cantare since there are only two runes to represent the spelling -tat or -tant (or the plural cantunt). Had the plural been vindicated, agone would have followed with the meaning 'in competition' (Norw. 'om kapp'). The only remaining possibility from the verbs suggested above is canere in the 3rd pers. sing. canit, and Knirk has confirmed that a reading it (I1) would fit perfectly with the last two runic remains: two staves of two-thirds height, missing their tops, and with no visible branches.

Also in favour of singular canit is the modal ablative agone that is now taken as 'in agony', 'in distress', 'in (spiritual) pain', and we should consider as likely the text avis canit a lucis agone 'a bird sings in agony from the groves', anticipating the nightingale and its transformation.

My result indicates that none of the bright and joyous attitude to love characterising the three stanzas in the first part of $C B 71$ (st. $1^{\mathrm{a}, \mathrm{b}}-2^{\mathrm{a}}$ and $3^{\mathrm{a}}$ ) has been transported to our text $\mathbf{c}$. To conclude, I prefer to read:

avis canit a lucis agone: filumena querule terea retractat

'A bird sings in agony from the groves: it is the nightingale (= Philomena) that woefully shuns the hoopoe (= Tereus).' 


\section{Conclusion}

In conclusion I interpret the ensemble in the following way:

(a) the youth declares his growing love for his sweetheart,

(b) he promises that he will act gently towards her when the two of them are together,

(c) lastly, he assures her that he will not transgress the ethical boundaries of courteous and Christian behaviour to cause her sorrow and spoil their relationship.

It is tempting to consider that the stick could have fulfilled a function similar to that of an engagement ring, bringing in written form the young man's declaration of love and his pledge to behave courteously and decently towards his beloved girl.

My proposal for a normalised and reconstructed text, as well as an English translation, is then as follows:

[Virginis e]gregie ignibus calesco; eius cotidie in amore cresco.

[Presen]s agam tenere, virgo; sic agamus: ambo sumus teneri.

[Avis canit] a lucis agone: filumena querule terea r[etractat.]

'In my passion for an outstanding [virgin] I am getting hot, and in my love for her I am getting stronger day by day.

[Face to face] I will act tenderly (gently), O virgin; let us act in such a way: we are both of tender age.

[A bird sings] in agony from the groves: it is the nightingale (= Philomena) that woefully [shuns] the hoopoe (= Tereus).'

\section{Acknowledgments}

I thank my anonymous referees and in particular James Knirk, my virtual co-author, for useful and indeed essential runological comments.

\section{Bibliography}

Anderson, William S., ed. 1982. Ovidius: Metamorphoses. 2nd ed. Bibliotheca Scriptorum Graecorum et Romanorum Teubneriana. Munich.

Bernt, Günter, ed./trans. 1992. Carmina Burana: Lateinisch/Deutsch. Reclam. Stuttgart.

Bourgain, Pascale, and Marie-Clotilde Hubert. 2005. Le latin médiéval. L'atelier du médiéviste, 10. Turnhout. 
Hilka, Alfons, and Otto Schumann. 1930-41. Carmina Burana. 2 vols. Heidelberg. Vol. 1, Text 1: Die moralisch-satirischen Dichtungen (1930); vol. 2, Kommentar, pt. 1: Einleitung (Die Handschrift der Carmina Burana), Die moralisch-satirischen Dichtungen (1930); pt. 2: Text 2: Die Liebeslieder (1941; containing the edition of $C B 88$ and 71).

Knirk, James E. 1990. "Rettingar og tillegg" and "Registre". In NIyR, 6(.2), 227-48 and 260-92.

— . 1998. "Runic Inscriptions Containing Latin in Norway." In Runeninschriften als Quellen interdisziplinärer Forschung: Abhandlungen des Vierten Internationalen Symposiums über Runen und Runeninschriften in Göttingen vom 4.-9. August 1995, ed. Klaus Düwel, 476-507. Reallexikon der Germanischen Altertumskunde, Ergänzungsbände, 15. Berlin.

— . 2017. "Love and Eroticism in Medieval Norwegian Runic Inscriptions." In Die Faszination des Verborgenen und seine Entschlüsselung: Rāði sār kunni: Beiträge zur Runologi, skandinavischen Mediävistik und germanischen Sprachwissenschaft [Festschrift for Edith Marold], ed. Jana Krüger, Vivian Busch, Katharina Seidel, Christiane Zimmermann and Ute Zimmermann, 217-32. Reallexikon der Germanischen Altertumskunde, Ergänzungsbände, 101. Berlin.

Liestøl, Aslak. 1980. = NIyR, 6(.1): 1-9.

$N I y R=$ Norges innskrifter med de yngre runer. Ed. Magnus Olsen et al. 6 vols. to date. Oslo, 1941-90.

Oxford Latin Dictionary. Ed. Peter G. W. Glare. Oxford, 1968-82.

Schumann, Otto. 1941. See Hilka and Schumann 1930-41, vol. 2, pt. 2.

Stotz, Peter. 1996-2004. Handbuch zur lateinischen Sprache des Mittelalters, vol. 3: Lautlehre (1996); vol. 4: Formenlehre, Syntax und Stilistik (1998). Handbuch der Altertumswissenschaft, 2nd ser., 5. Munich.

Suetonius. Nero. In De vita Caesarum, 86-186. Loeb Classical Library, 38. Cambridge, MA, 1913.

Vollmann, Benedikt K. 1987. Carmina Burana. Deutscher Klassiker Verlag; Bibliothek deutscher Klassiker. Frankfurt. Paperback ed. 2011.

Wetmore, Monroe Nichols. 1930. Index verborum Vergilianus. 2nd ed. New Haven, CT.

\section{Appendix}

A summary of Ovid's tale about Procne and Philomela and the Thracian king Tereus, Metamorphoses 6. 424-674:

Tereus, the terrifying king of Thrace, assisted King Pandion of Athens in a border conflict between the Athenians and the Thebans. When Pandion was victorious, he offered Tereus his daughter Procne in marriage. Ovid's account of this and its dreadful aftermath-almost a novelette in the style of the 
brothers Grimm-is told in grisly detail. A year after the couple's wedding a child called Itys was born. Five years later Procne longed to see her younger sister Philomela and asked Tereus to fetch her for a visit to Thrace. Pandion allowed Philomela to go under the protection of Tereus. On first sight Tereus, however, was overcome by lust for the beautiful girl and planned to make her his own. Philomela set off unsuspectingly with Tereus on his ship. As soon as they set foot on the Thracian shore, however, Tereus took her to a lonely hut where he raped her. To prevent her from revealing his crime, he cut out her tongue. Leaving Philomela under guard, he returned to his wife and told her that her sister was dead. A year passed, during which time Philomela wove a tapestry illustrating her sufferings. She managed to deliver the tapestry as a present through an old female servant. Procne immediately understood the secret message and brought Philomela to the palace in disguise. The revenge the sisters plotted against Tereus was horrific: Procne stabbed her little son Itys to death and cooked his flesh as part of a sumptuous meal to be served to Tereus at the religious festival he was attending. Enjoying the meal, Tereus asked his wife to fetch their son whereupon Procne presented her husband with his son's bloody head accompanied by all the verbal abuse she could muster. With a roar of rage, Tereus leapt up to kill the murderous sisters. The gods intervened, however, and turned all three of them into birds. In Ovid's classic version, Procne becomes the swallow, Philomela the nightingale and Tereus the hoopoe. 
